SSLA, 20, 51-81. Printed in the United States of America.

\title{
RECASTS, REPETITION, AND AMBIGUITY IN L2 CLASSROOM DISCOURSE
}

\author{
Roy Lyster \\ McGill University
}

\begin{abstract}
This study examines aspects of communicative classroom discourse that may affect the potential of recasts to be noticed as negative evidence by young second language learners. The database comprises transcripts of over 18 hours of interaction recorded during 27 lessons in $4 \mathrm{immersion}$ classrooms at the primary level. The 377 recasts in the database have been classified according to their pragmatic functions in classroom discourse and then compared to the teachers' even more frequent use of noncorrective repetition. Findings reveal that recasts and noncorrective repetition fulfill identical functions distributed in equal proportions and, furthermore, that teachers frequently use positive feedback to express approval of the content of learners' messages, irrespective of well-formedness, to accompany, also in equal proportions, recasts, noncorrective repetition, and even topic-continuation moves following errors. The findings suggest that, from the perspective of both learners and teachers, the corrective reformulations entailed in recasts may easily be overridden by their functional properties in meaning-oriented classrooms.
\end{abstract}

Results of this study were first reported in a plenary session at the Third European Conference on Immersion Programs, University of Barcelona (September 1996), followed by a paper at the meeting of the American Association of Applied Linguistics in Orlando, FL (March 1997). The study was funded by grants from the Social Sciences and Humanities Research Council of Canada (grant 410-94-0783) and from the Fonds pour la formation de chercheurs et l'aide à la recherche (grant 97-NC-1409). I am grateful to many research assistants for their participation in various phases of this study and, particularly, to France Bourassa and James Poirier for their reliable and stimulating contributions. I would also like to thank Nina Spada, Patsy Lightbown, and Leila Ranta for their continued support and feedback, as well as four anonymous reviewers for helpful comments on an earlier version.

Correspondence concerning this article should be addressed to Roy Lyster, Department of Second Language Education, McGill University, 3700 McTavish Street, Montreal, QC H3A 1Y2; e-mail: cxrl@musica. mcgill.ca.

○ 1998 Cambridge University Press $0272-2631 / 98 \$ 9.50$ 
The role of negative evidence (i.e., information about what is unacceptable in a given language) is an issue of growing concern in SLA research because it has implications that are equally important for both theory and practice. Research concerned with the role of negative evidence in first language (L1) acquisition examines the role of the linguistic environment in language development and whether any such role offsets the need to appeal to innate linguistic constraints in theories of language acquisition. In SLA research, in accordance with the interaction hypothesis, it has been proposed "that environmental contributions to acquisition are mediated by selective attention and the learner's developing L2 processing capacity, and that these resources are brought together most usefully, although not exclusively, during negotiation for meaning" (Long, 1996, p. 414). The latter is defined as "denser than usual frequencies of semantically contingent speech" containing various types of reformulation and repetition in addition to input modifications that "serve to make target forms salient independent of increased frequency" (p. 452). It is hypothesized that negotiation for meaning may provide learners with negative evidence that in turn may be facilitative of language development.

Recasts, defined as "utterances that rephrase a child's utterance by changing one or more sentence components ... while still referring to its central meanings" (Long, 1996, p. 434), constitute one such type of semantically contingent speech whose corrective potential has been examined in parent-child dyads (e.g., Bohannon \& Stanowicz, 1988; Farrar, 1990, 1992; Marcus, 1993; Morgan, Bonamo, \& Travis, 1995), in NS-NNS dyads (Long, Inagaki, \& Ortega, in press; Mackey \& Philp, in press; Oliver, 1995), and in teacher-student interaction in second language (L2) classrooms (Doughty, 1994; Doughty \& Varela, in press; Lyster, in press; Lyster \& Ranta, 1997; Roberts, 1995). Issues related to the role of recasts in SLA will be addressed in the present article, with particular reference to teacher-student interaction in communicatively oriented L2 classrooms where there is a primary focus on content. The article presents data to support the argument that the majority of recasts as used naturalistically by teachers in such contexts are unlikely to be either negotiated or noticed by young L2 learners as negative evidence.

In a recent analysis of participant organization in four French L2 immersion classrooms and four French L1 classrooms using Part A of the Communicative Orientation of Language Teaching (COLT) observation scheme (Spada \& Fröhlich, 1995), Fazio and Lyster (1997) found that $62 \%$ of the time in the L2 classrooms was spent in teacher-led whole-class activities. These classes were nonetheless considered to be communicatively oriented, according to the COLT analysis, particularly in relation to the four L1 classrooms, where $78 \%$ of the time was attributed to teacher-led whole-class activities. Given the frequency of teacher-led activities in these communicative classrooms, further analyses of teacher-student interaction are warranted yet require particular frameworks in order to characterize the nature of negotiated interaction as it relates to corrective discourse in communicatively oriented classrooms. One such framework was developed and applied in a recent observational study described by Lyster and Ranta (1997).

In that study, we presented an analysis of interaction in four primary immersion classrooms that revealed six different types of corrective feedback used by teachers. We found that recasts were by far the most widely used form of feedback: Of all the 
teachers' corrective feedback moves, more than half involved recasts. In our analysis of student turns immediately following teacher feedback (what we referred to as "uptake"), we found that $69 \%$ of recasts were followed by topic continuation; $18 \%$ were immediately repeated or incorporated by students, whereas $13 \%$ resulted in student utterances coded as "needs-repair." Recasts did not lead to any studentgenerated forms of repair because recasts already provide correct forms to learners.

These findings led us to suggest that teachers may need to implement a wider range of feedback techniques that they have at their disposal, and particularly (at least with learners possessing adequate levels of proficiency) those that lead to student-generated repair: namely, elicitation (e.g., "How do we say that in French?"), metalinguistic clues (e.g., "No, we don't say it that way"), clarification requests (e.g., "I don't understand"), and repetition of error (e.g., "Le girafe?"). These four techniques can initiate what we characterized as the negotiation of form in that they do not provide learners with correct forms and instead provide signals that engage learners more actively by assisting them to draw on what they already know (see also Lyster, 1994, 1995; Lyster \& Ranta, 1995). Unlike the negotiation of meaning, the negotiation of form aims not only for comprehensibility of message but also for accuracy and precision in form, thus involving a more pedagogical and less conversational function of negotiation.

We speculated that the negotiation of form may benefit L2 learning in two ways. First, corrective feedback that provides clues to learners to assist them in modifying their use of nontarget forms allows learners to actively confront errors in ways that may lead to revisions of their hypotheses about the target language (see Pica, Holliday, Lewis, \& Morgenthaler, 1989; Swain, 1993, 1995). Second, corrective feedback that invites student-generated repair in the form of self- or peer-repair provides opportunities for learners to proceduralize target-language knowledge that has already been internalized in declarative form (see Hulstijn, 1990; McLaughlin, 1990; Nobuyoshi \& Ellis, 1993; Towell, Hawkins, \& Bazergui, 1996).

We acknowledged the constraints of the analytic model that was designed to describe teacher-learner behavior in error treatment sequences turn-by-turn (the "needs-repair" category, however, can lead to additional feedback and thus allows for sequences that cross many turns). As in other studies of corrective feedback, learner responses immediately following feedback were taken into account in the analysis (for L1, see Bohannon \& Stanowicz, 1988; Demetras, Post, \& Snow, 1986; Farrar, 1992; Hirsh-Pasek, Treiman, \& Schneiderman, 1984; for L2, see Brock, Crookes, Day, \& Long, 1986; Chaudron, 1977; Doughty, 1994; Gass \& Varonis, 1989; Oliver, 1995). In this way, our operationalization of learner uptake allowed us to quantify student participation in the error treatment sequence and thus to characterize the students' productive involvement in classroom discourse related to error treatment. Although we maintain that learner uptake in the form of studentgenerated repair may benefit L2 learning for the reasons described above, it remains impossible to claim from such a descriptive study that uptake is itself an instance of L2 learning or that no uptake implies the absence of L2 learning. Clearly, L2 learning is a complex and time-consuming process that cannot be reduced to a learner's immediate response to corrective feedback. Researchers have been quick to dispel 
any false hopes that either the learner's repetition of the correct form or the use of alternative forms following feedback can be considered as evidence of learning (e.g., Corder, 1967; Gass, 1988; Gass \& Varonis, 1994; Long, 1977; Mackey \& Philp, in press; Schachter, 1983).

Nonetheless, many researchers have argued that "pushing" learners in their output may benefit their interlanguage development. Swain (1985) argued that learner production of modified output is necessary for L2 mastery and may result from ample opportunities for student output on the one hand and from the provision of useful and consistent feedback from teachers and peers on the other. More recently, Swain (1995) proposed that "modified, or reprocessed, output can be considered to represent the leading edge of a learner's interlanguage" (p. 131). Pica et al. (1989) found that such modified output occurred most often when native speakers signaled an explicit need for clarification rather than provided a model utterance for confirmation. In a study of the acquisition of past tense forms by six learners, Nobuyoshi and Ellis (1993) found at least short-term benefits (over one week) for some learners receiving such clarification requests.

Since some of the earliest classroom-based studies on error correction, many researchers have maintained that pushing learners in their output, rather than providing them with correct forms, may benefit their interlanguage development. In his seminal review of the literature on error correction, Hendrickson (1978) found that the procedure whereby teachers provide students with correct forms "is ineffective when helping students learn from their mistakes" (p. 393). He wrote of "a discovery approach to error correction" that would help students "to make inferences and formulate concepts about the target language, and to help them fix this information in their long-term memories." Allwright (1975), also with respect to error correction, suggested that "a method designed to force learners back on their own resources all the time may actually give more precise help than is usual elsewhere" (p. 98). Similarly, Corder (1967) argued that

simple provision of the correct form may not always be the only-or indeed the most effective-form of error correction since it bars the way to the learner testing alternative hypotheses. Making a learner try to discover the right form could often be more instructive to both learner and teacher (p. 168).

Vigil and Oller (1976) argued from a pedagogical viewpoint in favor of "negative feedback on the cognitive channel" to indicate problems in comprehension or the need for changes in output, creating "a desirable instability" in ill-formed utterances and pushing learners "to make appropriate modifications." (p. 288)

More recently, Allwright and Bailey (1991) suggested that "simple repetition or modeling of the correct form may be useless if the learners cannot perceive the difference between the model and the erroneous forms they produce" (p. 104); they recommended that L2 classroom learners be allowed "both time and opportunity ... for self-repair, whether it is self- or other-initiated" (p. 107). Chaudron (1988, p. 150 ) suggested that instruction which emphasizes self-correction in this way is more likely to improve learners' ability to monitor their own target-language speech. 
Likewise, van Lier (1988) argued that teachers should delay the use of corrective techniques that "deny the speaker the opportunity to do self-repair, probably an important learning activity" (p. 211), and Ellis (1997) suggested that learners may be learning "when they self-correct the errors they make" (p. 15).

With specific reference to recasts as a form of corrective feedback, Calvé (1992, p. 468) described them as remnants of audiolingualism that minimize the value of student utterances. He recommended that teachers, rather than drawing on such parroting techniques ("sans jouer les perroquets améliorés"), should give priority to self- and peer-correction and to techniques that provide learners with clues. Notwithstanding the passive role learners may play vis-à-vis recasts, their frequency in L2 classrooms has been well documented (Doughty, 1994; Fanselow, 1977; Lyster \& Ranta, 1997; Roberts, 1995). For example, Fanselow (1977) found that, although teachers did not draw on a wide range of techniques, the one corrective technique used by all 11 teachers in his sample was the recast. He concluded that "hypothesis testing, experimentation with language rules, seemed absent; congruence with the teachers' expectations seemed to be the rule" (p. 586). Furthermore, he found that teachers generally used such feedback in inconsistent and ambiguous ways (see also Allen, Swain, Harley, \& Cummins, 1990; Allwright, 1975; Chaudron, 1977; Long, 1977). Similarly, Netten (1991), based on observational data from a study of 23 Grade 1,2 , and 3 immersion classrooms, concluded that recasting "is not a sufficient way of indicating to pupils, particularly low achievers, that modification of their utterance is of some significance in order to communicate in the target language" (p. 304). She acknowledged the need for feedback that is less ambiguous from the L2 learner's perspective.

Although the potential ambiguity of recasts has been noted in L2 classroom studies, three controlled studies of the effects of recasts in laboratory situations have recently reported some short-term benefits for adult SLA. Long et al. (in press) described two experimental studies: one involving adult learners of Japanese receiving either recasts or models on two target structures (required adjective ordering and a preferred locative construction); the other involving 30 adult learners of Spanish receiving recasts and models related to object topicalization and adverb placement. Subjects in both the recast and model treatments were equipped with headphones as they played a communication game in dyads with a researcher. In the recast condition, subjects were prompted in their L1 to perform a specific task. As they performed the task, they described their action to the researcher who then recast their utterance. In the model condition, subjects heard a prerecorded prompt in the L2 and then repeated the prompt for the researcher who responded by performing the action. The authors found some short-term ${ }^{2}$ benefits for recasts over models among the learners of Spanish on adverb placement and among the learners of Japanese on both features, although they suggest that some subjects may have had latent knowledge of the Japanese structures due to prior instruction. Mackey and Philp (in press) conducted a laboratory experiment with 35 adult learners of ESL to compare the effects of interaction with and without recasts on the production and development of question forms. Each subject performed three information-gap tasks with a native-speaker researcher who either recast extensively or withheld recasts 
and instead used negotiation of meaning techniques. They found that advanced learners benefited more from the intensive recasts than from interaction without recasts.

The reported benefits of recasts in laboratory settings may be related to the context in which the data were collected. Procedures in laboratory settings may draw the participants' attention to language form despite efforts to create tasks that are communicatively based. This attention to language may be less characteristic of the interaction in communicatively oriented classrooms, particularly in classrooms where language is taught through content (see Swain, 1988, 1996) and experiential instructional approaches predominate (see Harley, 1993, 1994). In contrast with such classrooms, the dyadic interaction in laboratory settings is highly controlled and usually allows for only one language feature to be targeted-such decontextualization may facilitate a relatively explicit focus on form from the learner's perspective in ways that are difficult, if not impossible and likely undesirable, to reproduce in communicatively oriented classrooms. Thus, although laboratory studies have much to contribute to the development of SLA theory, their relevance to classroom practice remains limited, given the very different nature of classroom interaction with its multiplicity of purposes and foci.

Harley (1994) discussed SLA in content-based classrooms in the light of the noticing hypothesis: In order for input to become intake for L2 learning, some degree of noticing must occur, and what gets noticed in the input depends on mediating factors such as prior knowledge and skill, task demands, frequency, and perceptual salience (Gass, 1988; Schmidt, 1990, 1993). Harley argued that the experiential instructional approach underlying content-based instruction allows young learners to notice certain key aspects of the target system such as phonologically salient, high-frequency lexical items, along with syntactic patterns that are generally congruent with the L1. She argued that this "lexically-oriented learning can be seen to be well tuned to the task demands of their subject-matter learning where the most pressing need is for global comprehension and for the expression of meaning in context" (p. 62). At the same time, however, "less salient morphosyntactic features of the target system, incongruent with the $\mathrm{Ll}$ and/or not crucial for comprehension or for getting meaning across may fail to become intake."

The present study examines aspects of $\mathrm{L} 2$ classroom discourse that may minimize the perceptual salience of recasts and thereby limit their propensity to be noticed as negative evidence by young L2 learners in meaning-oriented classrooms. A detailed description is first presented of how four immersion teachers used four different types of corrective recasts in relation to different types of noncorrective repetition and positive feedback moves coded as signs of approval. The findings are then discussed in the light of other studies concerning the role of negative evidence in SLA, with particular reference to classroom-based SLA research.

\section{DATABASE}

The database used for analysis in the present study is the one described in detail by Lyster and Ranta (1997, pp. 42-43) and includes 27 lessons, totaling 1,100 minutes or 18.3 hours, taught by four French immersion teachers at the Grade 4/5 level. 
Teacher 3 (T3) teaches in an early total immersion program whereas Teachers 4, 5, and $6(\mathrm{~T} 4, \mathrm{~T} 5, \mathrm{~T} 6)$ teach in a middle immersion program beginning at Grade $4 .{ }^{3}$ There are 13 French language-arts lessons (7.8 hours) and 14 subject-matter lessons (10.5 hours) including lessons from science, social studies, and mathematics. The breakdown of the 27 lessons across the four teachers, including the date, duration, and topic of each lesson, is presented in the appendix.

The French language-arts lessons selected for analysis did not include formal grammar or spelling lessons. Instead, they involved a more communicative orientation, focusing on a variety of themes portrayed through diverse genres (e.g., short stories, classified ads, catalogues, letters written to companies, role-plays), in addition to class discussions about vacations, long weekend activities, and part-time jobs. All four teachers tended to adopt the Whole Language approach, thus minimizing explicit language instruction and integrating language skills across disciplines. Some were so adept at effacing borders between language classes and content classes that the investigators often had to inquire as to whether they were observing a language class or a content class. The teachers knew only that the research team was interested in recording classroom interaction and were asked to continue with their usual way of teaching as they were observed and tape-recorded. Even when students were involved in group work, teacher-student interaction remained in focus as the teachers, wearing a wireless microphone, went from group to group interacting with students.

Following Doughty (1994), the transcripts selected for analysis were imported into COALA (Computer Aided Linguistic Analysis, Thornton \& Pienemann, 1994), which allowed for the coding and quantification, for the purposes of the present study, of a set of semantically contingent replies used by the four teachers and consisting of different types of recasts, noncorrective repetition, and signs of approval (definitions of these coding categories are provided below in their respective sections). As these more detailed coding categories were being developed, three new members of the research team were able to improve the quality of the transcripts by transcribing a small number of previously unintelligible utterances and, accordingly, to agree on minor revisions to the original coding. As a result, the database used for analysis in the present study includes a total of 3,387 student turns: 2,264 student turns without error and 1,123 student turns containing at least one error or coded as "needs-repair." The total number of teacher turns with corrective feedback is 699 ; this includes 377 recasts.

\section{RECASTS}

The present study is part of a larger program of research that has as one of its long-term goals a classroom experiment designed to investigate the variable effects of different types of corrective feedback on L2 learning. Results of the descriptive study presented by Lyster and Ranta (1997) suggested that a further examination of recasts should precede such an experimental study for two reasons: first, due to their overwhelming frequency ( $55 \%$ of all teacher feedback turns involved recasts) and, second, due to the low rate of repair that resulted (only $18 \%$ of teacher recasts 
were immediately followed by student repair, and when there was repair, it merely involved repetition or incorporation of the recast). More needed to be known about how teachers use recasts naturalistically in communicatively oriented classrooms (i.e., where the primary focus is on subject matter or on content-related themes in language arts). Accordingly, the present study was designed to examine the discourse contexts in which recasts naturally occur and whether these contexts appear to provide young classroom learners with helpful opportunities to notice the gap between their initial erroneous utterance and the teacher's corrective reformulation (see Schmidt, 1990; Schmidt \& Frota, 1986). In the ensuing analysis, the functional properties of the 377 recasts used by the four teachers are examined and then discussed in terms of how such properties might affect the corrective potential of recasts.

\section{Coding}

In view of the corrective feedback used by the four teachers described by Lyster and Ranta (1997, pp. 46-47), recasts were defined as the teacher's implicit provision of a correct reformulation of all or part of a student's ill-formed utterance. The present analysis of their functional properties in classroom discourse revealed four types of recasts.

Type 1. An isolated declarative recast provides confirmation of a learner's message by correctly reformulating all or part of the utterance with falling intonation and no additional meaning.

(1) (T3, Language Arts, Feb. 6$)^{4}$

St: Avant que quelqu'un le prendra.

"Before someone will takes it."

T3: Avant que quelqu'un le prenne.

"Before someone takes it."

Type 2. An isolated interrogative recast seeks confirmation of the learner's message by correctly reformulating all or part of the utterance with rising intonation and no additional meaning.

(2) (T4, Language Arts, Mar. 17)

St: On pense que, qu'il est prisonnière, comme, um, quelque part.

"They think that, that he's a prisoner [feminine form], like, um, somewhere."

T4: Prisonnier?...

"Prisoner?..."

Type 3. An incorporated declarative recast provides additional information by incorporating the correct reformulation of all or part of a learner's utterance into a longer statement.

(3) (T5, Language Arts, Mar. 14)

St: Ou une bateau.

"Or a boat." 
T5: Oui, c'est vrai que ça pourrait être un bateau, mais là on donne des adresses. "Yes, that's true that it could be a boat, but there they're giving addresses."

Type 4. An incorporated interrogative recast seeks additional information by incorporating the correct reformulation of all or part of a learner's utterance into a question.

(4) (T3, Science, Jan. 16)

St: Elle changer de couleur. "It change color."

T3: Pourquoi elle change de couleur? "Why does it change color?"

Thus, in addition to their function of implicitly providing a reformulation of all or part of an ill-formed utterance, recasts serve to respond to the semantic content of a learner's utterance by (a) providing or (b) seeking confirmation of the learner's message, or by (c) providing or (d) seeking additional information related to the learner's message.

This inclusive classification takes account of recasts as they occur in classroom discourse. Type 1 comprises typical recasts that are common across many, if not all, studies of recasts (see Richards, 1994). Type 2 includes confirmation checks, which have been distinguished from recasts in some studies even though confirmation checks fulfill a particular discourse function in sequentially contingent speech that may include corrective rephrasing. Because confirmation checks and recasts are not mutually exclusive, the comparison of confirmation checks as negotiation strategies on the one hand, to recasts on the other, may result in coding categories that overlap in studies designed to make such comparisons (e.g., Mackey \& Philp, in press; Oliver 1995). However, coding schemes in these studies have accounted for potential overlap: For example, Oliver (1995) designed a hierarchical scale to rank responses so that recasts overrode negotiation strategies; that is to say, a recast serving as a confirmation check was coded as a recast, not a negotiation strategy. ${ }^{5}$

The inclusion of Types 3 and 4 may appear to differ from studies that have defined recasts as semantically contingent rephrasings that contain no additional information. However, recasts, expansions, and other types of repetition have been operationalized inconsistently across studies (see Marcus, 1993; Richards, 1994). As a result, whether or not recasts include additional information is also variable across studies, although ample support can be found to account for corrective reformulations that add new information. For example, in earlier studies not using the term recast, the term expansion was generally used to refer to semantically contingent speech containing corrective reformulations and extension to account for new information (e.g., Penner, 1987; Snow, 1988). However, Morgan and Travis (1989) referred to corrective reformulations as expansions but included in this category repetitions providing only corrections as well as corrective repetitions providing new information (e.g., "That why Jacky comed $\rightarrow$ Yes, Jacky came yesterday ... yesterday afternoon"). A recast in the Bohannon and Stanowicz (1988) study was considered to preserve the child's meaning but replace certain elements, whereas an 
Table 1. Number and percentage of four types of recasts $(N=377)$

\begin{tabular}{lrcr}
\hline & Declarative & Interrogative & \multicolumn{1}{c}{ Total } \\
\hline Isolated & $251(67 \%)$ & $46(12 \%)$ & $297(79 \%)$ \\
Incorporated & $64(17 \%)$ & $16(4 \%)$ & $80(21 \%)$ \\
Total & $315(84 \%)$ & $62(16 \%)$ & $377(100 \%)$ \\
\hline
\end{tabular}

expanded repetition was considered to reproduce major elements of the child's utterance and add new information. However, their example of an expanded repetition contained, as in Type 3, a corrective modification: "Monkey climbing $\rightarrow$ The monkey is climbing to the top of the tree." Similarly, in Morgan et al. (1995), recasts were not considered separately from expansions but rather as subcategories of expansion (including recasts coded as minimal, expanded, related, or other) and in Marcus's (1993) summary of definitions used across several studies, recasts and expansions both entailed parental repetitions of child utterances, the former including minor grammatical changes and the latter including grammatical changes or new material. Recasts that elicit additional information, as in Type 4, have been accounted for in Saxton's (1997, pp. 145-146) recent analysis of negative evidence in L1 contexts, as illustrated in the following example: "Do you know how Big Foot was BORNED? $\rightarrow$ No, how was he BORN?" In Oliver's (1995) L2 study of interactional moves in young NS-NNS dyads, responses were coded as recasts if they contained corrective reformulations and maintained the central meaning of the previous turn. Responses providing additional information were considered to be expansions, generally coded as topic continuations unless they too contained a corrective reformulation, in which case the expansions were coded as recasts. ${ }^{6}$

\section{Results}

As shown in Table 1, the breakdown of the four types of recasts revealed the largest category to be Type 1 , which accounted for $67 \%$ of all recasts. Therefore, together with Type 2 recasts that served as confirmation checks, $79 \%$ of all recasts were isolated reformulations that neither provided nor sought additional information related to content. Only $21 \%$ of the recasts were considered to be incorporated in that they either provided or sought additional information-focusing the learner's attention more on content and perhaps camouflaging the reformulation, as in the example of Type 3 above. On the basis of these figures, then, one might speculate that almost $80 \%$ of all recasts were able to focus the learners' attention on form.

However, as displayed in Table 2 and illustrated by the examples below, an analysis of uptake following the four types of recasts suggests that the ways in which the teachers used even isolated recasts may not necessarily draw attention to form either. As one might expect, of the 80 incorporated recasts, none led to any repair, $8(10 \%)$ led to needs-repair, while the remaining $72(90 \%)$ led to topic-continuation moves ( 59 initiated by teacher and 13 by students). With respect to the 297 isolated recasts, only $68(23 \%)$ led to repair and $40(13 \%)$ led to needs-repair, whereas 190 
Table 2. Learner uptake versus topic continuation following four types of recasts $(N=377)$

\begin{tabular}{|c|c|c|c|c|c|c|}
\hline & \multicolumn{3}{|c|}{ Isolated Recasts } & \multicolumn{3}{|c|}{ Incorporated Recasts } \\
\hline & $\begin{array}{c}\text { Type I } \\
(n=251)\end{array}$ & $\begin{array}{l}\text { Type } 2 \\
(n=46)\end{array}$ & $\begin{array}{l}\text { Total \% } \\
(n=297)\end{array}$ & $\begin{array}{l}\text { Type } 3 \\
(n=64)\end{array}$ & $\begin{array}{c}\text { Type } 4 \\
(n=16)\end{array}$ & $\begin{array}{l}\text { Total } \% \\
(n=80)\end{array}$ \\
\hline \multicolumn{7}{|l|}{ Learner uptake } \\
\hline Repair & 66 & 1 & $23 \%$ & 0 & 0 & - \\
\hline Needs-repair & 27 & 13 & $13 \%$ & 5 & 3 & $10 \%$ \\
\hline $\begin{array}{l}\text { Topic continuation } \\
\text { (teacher + student) }\end{array}$ & $\begin{array}{c}158 \\
(123+35)\end{array}$ & $\begin{array}{c}32 \\
(24+8)\end{array}$ & $\begin{array}{c}64 \% \\
(50 \%+14 \%)\end{array}$ & $\begin{array}{c}59 \\
(50+9)\end{array}$ & $\begin{array}{c}13 \\
(9+4)\end{array}$ & $\begin{array}{c}90 \% \\
(74 \%+16 \%)\end{array}$ \\
\hline
\end{tabular}

(64\%) led to topic-continuation moves. Thus, almost two thirds of the isolated recasts provided no opportunities for uptake, as illustrated in the following examples:

(5) (T5, Science, Apr. 11)

St: Euh ... lapin de ... un désert? [Error]

"Um ... rabbit of ... a desert?"

T5: Lapin du désert? [Type 2 recast] Non, non y vivent pas dans l'désert ces lapins-là. Ils vivent plutôt dans la forêt. [Topic continuation]

"Desert rabbit? No, no those rabbits don't live in the desert. They tend to live in the forest."

(6) (T3, Math, Jan. 16)

T3: Réduction...

"Reduction..."

St: De la moitié. [Error]

"By the half."

T3: De moitié. [Type 1 recast] Est-ce que tout le monde comprend ça? [Topic continuation]

"By half. Does everyone understand that?"

(7) (T4, Social Studies, Mar. 31)

T4: Et le garçon, lui, s'appelle?

"And the boy, he's called?"

St: Moi, s'appelle Jacques. [Error]

"Me, called Jacques."

T4: Il s'appelle Jacques. [Type 1 recast] Robert, d'autres noms? [Topic continuation] "He's called Jacques. Robert, any other names?"

Thus, while reducing the salience of the corrective reformulations entailed in recasts, the numerous topic-continuation moves immediately following recasts allowed teachers to keep the floor and, concomitantly, to keep their students' attention focused on content or on classroom procedures. In this sense, recasting does not invite negotiation. Indeed, many recasts-even so-called isolated ones-were followed by such long topic-continuation moves that the coding of endpoints in such moves proved to be rather arbitrary.

Finally, of the 251 isolated declarative recasts classified as Type 1, 92 involved a reduction of the learner's utterance. Chaudron (1977) found that when the teacher's utterance employed only a segment of the student's utterance in this way, the 
Table 3. Recasts with reduction

\begin{tabular}{ll}
\hline Total recasts & 377 \\
Recasts with reduction & 92 (24\% of all recasts) \\
Total repair after recasts & 68 \\
Repair after recasts with reduction & 50 (74\% of all repairs after recasts) \\
\hline
\end{tabular}

chances for successful learner uptake were greater (see also Roberts, 1995, regarding the noticeability of partial recasts). Indeed, as displayed in Table 3 , of the 92 recasts with reduction, over half led to repair, and these 50 repairs accounted for three quarters of all repairs following recasts. The 92 reduced recasts appear then to be the most effective, yet accounted for less than one quarter of all 377 recasts.

To summarize, in addition to their function of implicitly providing learners with rephrasings of erroneous utterances, recasts fulfilled other functions by providing confirmation or additional information related to content and, to a lesser degree, by seeking confirmation or additional information. Even though two thirds of all recasts were isolated declarative forms that included no additional information, the numerous topic-continuation moves that followed such recasts allowed teachers to keep students' attention focused on content or on procedural matters. In meaning-oriented classrooms, therefore, the corrective function of recasts may be less salient than their various discourse functions.

\section{NONCORRECTIVE REPETITION}

This section reports on a phenomenon that even further reduced the salience of recasts in teacher-student interaction. In addition to recasts, teachers tended to use a great deal of noncorrective repetition; that is, they often repeated students' well-formed utterances.

Other studies of teacher feedback have made similar observations. For example, Fanselow (1977) found that teachers presented the right answer after correct as well as incorrect responses, thereby displaying identical behavior for two separate purposes (see also Allwright, 1975; Long, 1977). Chaudron (1988) observed that such ambiguous behaviour constitutes one of the most noted problems with corrective feedback: "'repetition' of a speaker's utterance can serve several functions, of either a negative (correcting) or a positive nature (agreeing, appreciating, understanding ... )" (p. 145), thus leading to a problem for $\mathrm{L} 2$ learners for whom "the modification may be imperceptible, or perceived as merely an alternative to their own utterance, because accepting, approving, confirming repetitions occur frequently in the same contexts" (pp. 145-149).

\section{Coding}

To examine how easily classroom learners might distinguish recasts from other types of repetition, the forms and functions of noncorrective repetition were examined to determine in what ways they differed from corrective recasts. Interestingly, 
the analysis revealed that noncorrective repetitions perform the same pragmatic functions in classroom discourse as do recasts; these in turn have been classified as four types of noncorrective repetition.

Type 1. An isolated declarative repetition provides confirmation of the learner's message by repeating all or part of the utterance with falling intonation and no additional meaning.

(8) (T6, Science, May 11)

St: Un animal brun

"A brown animal."

T6: Un animal brun.

"A brown animal."

Type 2. An isolated interrogative repetition seeks confirmation of the learner's message by repeating all or part of the utterance with rising intonation and no additional meaning.

(9) (T3, Language Arts, Jan. 16)

St: Il faut qu'ils fassent plein de travail.

"They have to do a lot of work."

T3: Il faut qu'ils fassent plein de travail?

"They have to do a lot of work?"

Type 3. An incorporated declarative repetition provides additional information by incorporating all or part of a learner's utterance into a longer statement.

(10) (T5, Science, Mar. 28)

St: C'est un animal sauvage.

"It's a wild animal."

T5: C'est un animal sauvage qui habite dans une tanière. Bien, alors . . "It's a wild animal that lives in a den. Good, so ..."

Type 4. An incorporated interrogative repetition seeks additional information by incorporating all or part of a learner's utterance into a question.

(11) (T3, Language Arts, Feb. 6)

St: Un livre populaire?

"A popular book?"

T3: Un livre populaire, ça s'appelle un ... ?

"A popular book, that's called a ...?"

Noncorrective repetitions thus fulfill the same functions as recasts in that they respond to the semantic content of a learner's utterance by (a) providing or (b) seeking confirmation of the learner's message, or by (c) providing or (d) seeking additional information related to the learner's message. 
Table 4. Number and percentage of student turns in total database $(N=3,387)$ followed by recasts and noncorrective repetition

\begin{tabular}{lll}
\hline Followed by recasts & 377 & $(11 \%)$ \\
Followed by noncorrective repetitions & 617 & $(18 \%)$ \\
Total & 994 & $(29 \%)$ \\
\hline
\end{tabular}

Table 5. Distribution of four types of recasts and noncorrective repetition

\begin{tabular}{lrrrr}
\hline & Recasts & \multicolumn{2}{c}{$\begin{array}{c}\text { Noncorrective } \\
\text { Repetition }\end{array}$} \\
\hline Isolated & & & & \\
$\quad$ Type 1 (declarative) & 251 & $(67 \%)$ & 427 & $(69 \%)$ \\
Type 2 (interrogative) & 46 & $(12 \%)$ & 49 & $(8 \%)$ \\
Incorporated & & & & \\
$\quad$ Type 3 (declarative) & 64 & $(17 \%)$ & 101 & $(17 \%)$ \\
Type 4 (interrogative) & 16 & $(4 \%)$ & 40 & $(6 \%)$ \\
Total & $377(100 \%)$ & $617(100 \%)$ \\
\hline
\end{tabular}

\section{Results}

In terms of frequency, the teachers tended to recast a slightly higher proportion of ill-formed utterances in comparison to their repetitions of well-formed utterances: Of the 1,123 student turns with error in the database, $377(34 \%)$ were followed by a teacher's corrective recast, whereas $617(27 \%)$ of the 2,264 student turns without error were followed by a teacher's noncorrective repetition. However, because there were twice as many error-free turns in the database as erroneous turns, the number of noncorrective repetitions exceeded that of corrective recasts, as displayed in Table 4. Of the total number of student turns in the database, $11 \%$ were followed by a teacher's corrective recast and $18 \%$ were followed by a teacher's repetition of a nonerror. This means that almost $30 \%$ of all student utterances in the database were followed by either a corrective recast or a noncorrective repetition, thus revealing a considerable amount of echoing in these classrooms.

Particularly striking are the identical patterns that appear in the distribution of recasts and noncorrective repetition across the four types. As displayed in Table 5 and in Figure 1, a comparison of recasts and noncorrective repetitions indicates that 67-69\% were isolated declarative forms (Type 1), 8-12\% were isolated interrogative forms (Type 2), 17\% were incorporated declarative forms (Type 3), and 4-6\% were incorporated interrogative forms (Type 4).

In addition to these similar functional patterns, $95(15 \%)$ of the noncorrective repetitions further resembled recasts in that they were not verbatim repetitions. Some contained minor noncorrective changes in syntax or morphology as in (12); in others, teachers changed first-person reference to second-person reference, as in (13). 


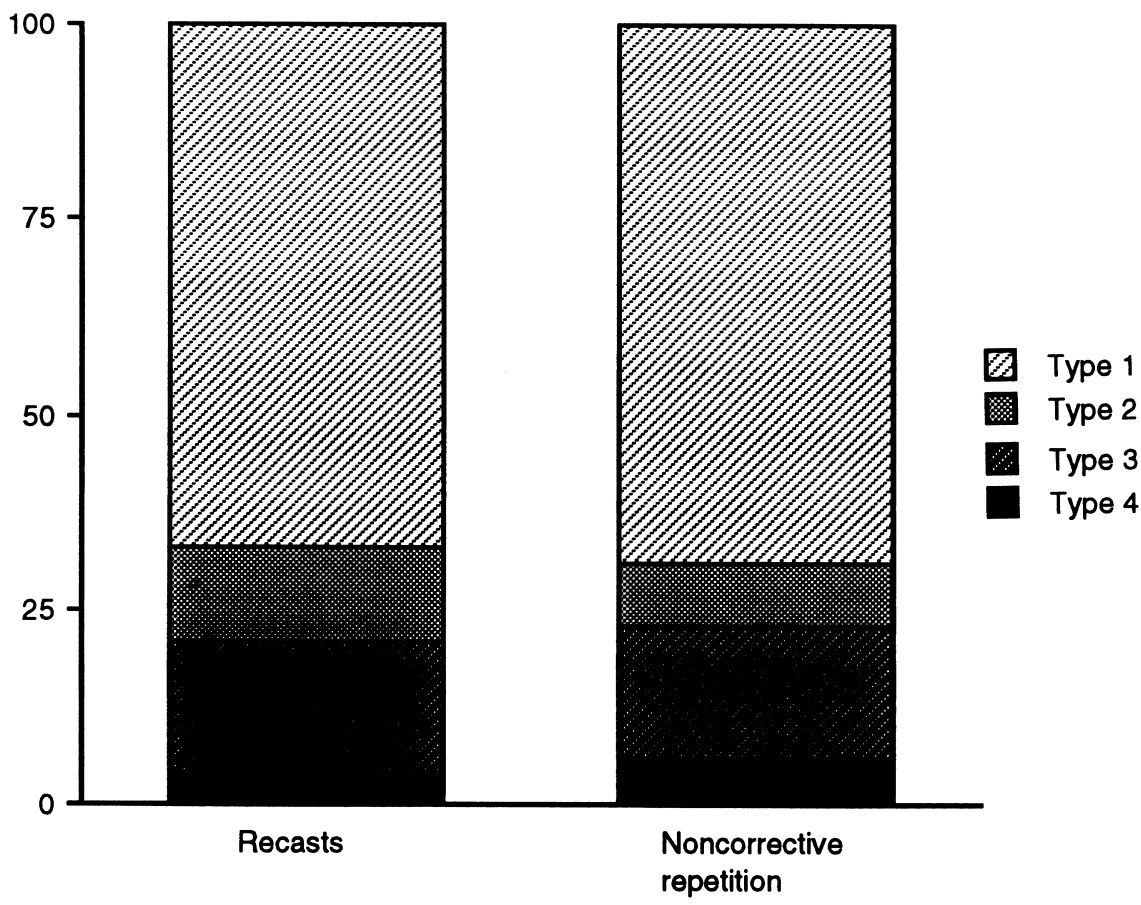

Figure 1. Percentage distribution of four types of recasts and noncorrective repetition.

(12) (T3, Language Arts, Mar. 20)

St: Des, congés. On prend des congés.

"Holidays. We take holidays."

T3: On va prendre des congés, oui!

"We're going to take holidays, yes!"

(13) (T3, Language Arts, Mar. 8)

St: Elle me donne rien.

"She gives me nothing."

T3: Elle te donne rien.

"She gives you nothing."

Accordingly, one may well wonder, first, how L2 learners can distinguish the purpose of recasts from the purpose of noncorrective repetitions and, second, whether the teachers' intention in recasting is indeed to correct form or if their intention has more to do with content. Whether a teacher's contingent reply contained a recast or a noncorrective repetition, it served either to provide or seek confirmation or to provide or seek additional information. Table 6 presents further examples of recasts and noncorrective repetition across each of these four functions. The comparison leads to the conclusion that the formal properties entailed in the corrective reformulations of recasts may easily be overridden by their functional properties in meaningoriented classrooms. 
Table 6. Comparison of recasts and noncorrective repetition across four functions

\begin{tabular}{|c|c|c|}
\hline Function: & Recasts & Noncorrective Repetition \\
\hline Type 1: & T3-Language Arts-Jan. 16 & T3-Science-Jan. 16 \\
\hline $\begin{array}{l}\text { Isolated declarative forms } \\
\text { used to provide confirmation }\end{array}$ & $\begin{array}{l}\text { St: Oui, c'est le assistante. } \\
\text { "Yes, it's the assistant." } \\
\text { T3: C'est l'assistante. Ensuite } \\
\text { c'est ...? } \\
\text { "It's the assistant. Next } \\
\text { it's ...?" }\end{array}$ & $\begin{array}{l}\text { St: C'est le cerf de Virginie. } \\
\text { "It's the white-tailed } \\
\text { deer." } \\
\text { T3: Donc le cerf de Virginie. } \\
\text { Qu'est-ce que c'est, lui, le } \\
\text { cerf de Virginie? } \\
\text { "So it's the white-tailed } \\
\text { deer. What is the white- } \\
\text { tailed deer?" }\end{array}$ \\
\hline Type 2: & T5-Science-April 11 & T3-Science-Jan. 16 \\
\hline $\begin{array}{l}\text { Isolated interrogative forms } \\
\text { used to seek confirmation }\end{array}$ & 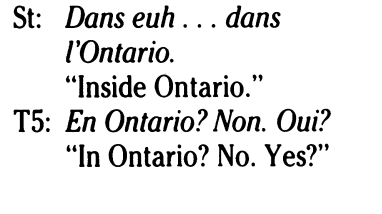 & $\begin{array}{l}\text { St: La grandeur de ta règle. } \\
\text { "The size of your ruler." } \\
\text { T3: La grandeur de ta règle? } \\
\text { Excellent. À-peu-près. } \\
\text { "The size of your ruler? } \\
\text { Excellent. Just about." }\end{array}$ \\
\hline Type 3: & T3-Language Arts-Mar. 8 & T5-Science-April 11 \\
\hline $\begin{array}{l}\text { Incorporated declarative } \\
\text { forms used to provide addi- } \\
\text { tional information or com- } \\
\text { mentary }\end{array}$ & 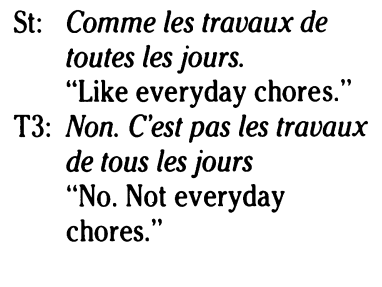 & $\begin{aligned} & \text { St: } \text { Ah, euhm ... mille neuf } \\
& \text { cent vingt-sept. } \\
& \text { "Ah, uhm ... nineteen } \\
& \text { twenty-seven." } \\
& \text { T5: } \\
& \text { Non, c'était pas en mille } \\
& \text { neuf cent vingt-sept. } \\
& \text { "No, it wasn't in nineteen } \\
& \text { twenty-seven." }\end{aligned}$ \\
\hline Type 4: & T5-Science-April 4 & T3-Math-Jan. 16 \\
\hline $\begin{array}{l}\text { Incorporated interrogative } \\
\text { forms used to seek additional } \\
\text { information or commentary }\end{array}$ & $\begin{array}{l}\text { St: C'est comme le céréale. } \\
\text { "It's like cereal." } \\
\text { T5: Est-ce que tout le monde } \\
\text { est d'accord avec ca, que } \\
\text { les galettes de riz c'est } \\
\text { comme des céréales? Oui? } \\
\text { "Does everyone agree } \\
\text { with that, that rice cakes } \\
\text { are like food grains? } \\
\text { Yes?" }\end{array}$ & 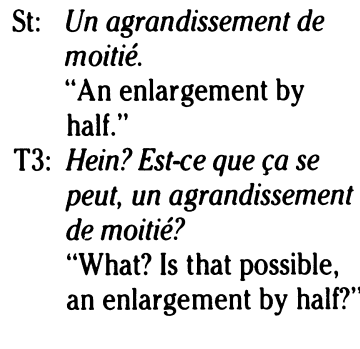 \\
\hline
\end{tabular}

Given this ambiguity concerning what learners might perceive in the input, uptake was again examined in order to determine how learners responded in turns immediately following teachers' noncorrective repetitions. As indicated in Table 7 , after only $5 \%$ of the teacher's noncorrective repetition did students repeat, or acknowledge with a oui ("yes") or a non ("no"); the other $95 \%$ of the time, there was topic continuation. Thus, although recasts did not invite much uptake in comparison to other feedback types, the $31 \%$ uptake that did follow recasts is considerably more than the $5 \%$ uptake following noncorrective repetition. ${ }^{i}$ Of the $31 \%$ uptake following 
Table 7. Learner uptake versus topic continuation following recasts and noncorrective repetition

\begin{tabular}{lccccc}
\hline & \multicolumn{2}{c}{ Learner Uptake } & & No Uptake \\
\cline { 2 - 3 } \cline { 5 - 6 } & $\begin{array}{c}\text { Student Repeats/ } \\
\text { Incorporates }\end{array}$ & $\begin{array}{c}\text { Acknowledgement } \\
\text { or Other “Needs" }\end{array}$ & & $\begin{array}{c}\text { Topic Continuation } \\
\text { (teacher + student) }\end{array}$ \\
\hline $\begin{array}{l}\text { Following recasts }(n=377) \\
\begin{array}{l}\text { Following noncorrective } \\
\text { repetition }(n=617)\end{array}\end{array}$ & $68(18 \%)$ & $48(13 \%)$ & & $261(205+56)(69 \%)$ \\
\hline
\end{tabular}

recasts, however, only $18 \%$ included repair in the form of correct repetition or incorporation (the other $13 \%$ involved student utterances still in need of repair, including simple acknowledgements such as oui). The reader will recall from the preceding section that $24 \%$ of all recasts entailed reductions of the learner's utterance and that these reduced recasts accounted for three quarters of all repairs following recasts. In contrast, only $54(9 \%)$ of all noncorrective repetitions in the database entailed reductions of the learner's utterance. That a higher proportion of recasts in comparison to noncorrective repetitions entailed a reduction of the learner's utterance may account, in part, for the higher proportion of uptake following recasts. In addition, it may be the case that teachers, when their intentions were indeed to correct, provided additional signals, which were not detected in the transcripts, that distinguished some recasts from noncorrective repetitions (e.g., waiting longer or looking at students in ways that invited uptake).

\section{REPETITION AS CORRECTIVE FEEDBACK}

In Lyster and Ranta (1997), the teachers' isolated repetition of learner errors, as a form of corrective feedback, represented only $5 \%$ of all teacher feedback moves. However, we also reported that repetition of error occurred in combination with other feedback types. Because various types of repetition in classroom discourse are the object of investigation in the present study, this brief section presents a detailed breakdown of repetition as corrective feedback in isolation and in combination, which together represented $13 \%$ of all teacher feedback turns.

Of the total 699 feedback turns, repetition as corrective feedback was distributed in the following ways:

\section{In Isolation 38 Times (5\%)}

(14) (T5, Science, Apr. 25)

$$
\begin{aligned}
& \text { St: On est fini. } \\
& \text { "We is finished." } \\
& \text { T5: On est fini? }
\end{aligned}
$$

"We is finished?" 


\section{In Combination 53 Times (8\%)}

with metalinguistic clues (20 times):

(15) (T3, Language Arts, Mar. 20)

St: Pis euhm, j'ai allé, au. . .

"Then um, I am gone to the ..."

T3: "J'ai allé" ça ne se dit pas.

"You can't say, 'I am gone."”

with elicitation (15 times):

(16) (T3, Math, Jan. 16)

St: Rapetissement?

"Shortening?"

T3: Un rapetissement. Comment on pourrait dire ça? Un autre mot pour rapetissement? "A shortening. How could we say that? Another word for shortening?"

with explicit correction (11 times):

(17) (T6, Language Arts, Apr. 3)

St: Des oeufs [œ].

"Eggses."

T6: Des oeufs [œ]. On dit pas des oeufs [œf]. On dit des oeufs [œ]. On prononce pas le "f."

"Eggs. We don't say 'eggses' [œf]. We say 'eggs' [œ]. We don't pronounce the 'f.'”

with clarification request ( 6 times):

(18) (T3, Language Arts, Mar. 29)

St: J'ai réussi ma lettre.

"I succeeded my letter."

T3: Je comprends pas, t'as réussi ta lettre.

"I don't understand, you succeeded your letter."

with recast (1 time):

(19) (T3, Social Studies, Jan. 30)

St: Y a des maisons qui sont faites en roches.

"There are houses built of rock."

T3: En roches, en pierres.

"Of rock, of stone."

An examination of uptake following corrective repetition in combination with other feedback types indicated that these combinations are relatively effective. Of the 53 instances, 29 led to repair, resulting in the highest rate of repair (55\%) in comparison to all other feedback types; 18 more led to needs-repair, resulting in the second highest rate, after elicitation, of uptake $(89 \%){ }^{8}$

\section{SIGNS OF APPROVAL}

The search for potential ambiguity in classroom discourse led finally to a detailed analysis of the teachers' use of positive feedback (Long, 1977, p. 283), or what we initially coded as reinforcement moves in Lyster and Ranta (1997). For the purposes 
of the present study, these moves have been coded as signs of approval (see Brown \& Hanlon, 1970, and also Penner, 1987, who coded a similar move in L1 parent-child interaction as verbal agreement/approval).

\section{Coding}

Three types of statements used by the teachers were coded as contingent signs of approval (paralinguistic signs were not analyzed), occurring either alone or in various combinations: (a) simple affirmation or acknowledgement (oui; OK; bien sûr; mais oui; ben oui; c'est ça; d'accord; these were often used to mean "I accept what you say"); (b) praise markers (e.g., Très bien; Excellent; Bravo!); and (c) repetition of the student's repair (which could also include additional metalinguistic information or commentary). As we developed the model for coding error treatment sequences presented in Lyster and Ranta (1997, p. 44), we expected approval to be expressed after student repair. However, it was subsequently found that signs of approval occurred not only after repair, but also at other unexpected points in the sequence: They occurred immediately following students' errors and also following teachers' recasts. This typically involved a teacher responding affirmatively to the content and then ignoring the error by moving on to topic continuation, or responding affirmatively to the content and then recasting the learner's error, or recasting the error and then responding affimatively to the content. The following examples illustrate these various positions:

\section{After Error (Before Topic Continuation)}

(20) (T3, Math, Jan. 16)

St: Moi j'ai arrivée au fin. [Error]

"I am got to end."

T3: OK. Très bien. [Approval] Bon, on est supposé d'avoir presque le numéro un de fait. Je vais aller voir. [Topic continuation]

"OK. Very good. Alright, we should have number one almost done. I'm going to see."

(21) (T4, Social Studies, Mar. 31)

St: Oh! OK. Oh, oh, que c'est bon! J'aime les truquages quand le train va lumière vitesse. [Error]

"Oh! OK. Oh, oh, it's great! I like the special effects when the train goes speed light."

T4: C'est bien alors, ils discutent le le film. C'est bien, excellent, George. [Approval] $O K$, Patrick. [Topic continuation]

"That's good, and so they're discussing the film. Good, excellent, George. OK, Patrick."

\section{After Recasts (Before Topic Continuation)}

(22) (T3, Language Arts, Mar. 20)

St: Est-ce que c'est dans, j'pense que c'est dans l'Europe. [Error]

"Is it in, I think it's inside Europe." 
T3: C'est en Europe. [Recast] Oui, tu as raison. [Approval]

"It's in Europe. Yes, you're right."

(23) (T6, Language Arts, Apr. 10)

T6: Le trou dans lequel vit un lapin, Patrick?

"A hole in which a rabbit lives, Patrick?"

St: Un terrière. [Error]

"A din."

T6: Un terrier, [Recast] c'est bon. [Approval]

"A den, that's good."

\section{After Error (Before Recast)}

(24) (T5, Science, Apr. 25)

T5: C'est quoi ça des ordres? Oui?

"What are orders? Yes?"

St: C'est des, juste comme euh tu dis à nous euh, "fais ça, fais ça." [Error]

"It's, just like uhh you tell to us uhh, 'do this, do that."

T5: Exactement, [Approval] c'est quand quelqu'un nous dit, "Fais ça, va là, comme ça, mange ça." [Recast]

"Exactly, it's when someone tells us 'Do that, go there, like that, eat that."'

(25) (T6, Language Arts, Apr. 3)

St: Cabine à sucre. [Error]

"Sugar cabeen."

T6: Parfait. [Approval] Alors la cabane à sucre. [Recast] La place où nous allons aller visiter la semaine prochaine. Parfait.

"Perfect. The sugar cabin. The place where we'll be going to visit next week. Perfect."

\section{Results}

In the 921 error treatment sequences in the present database, teacher moves coded as signs of approval occurred 319 times. The frequency distribution of these moves across the various positions is presented in Table 8. As expected, many signs of approval (34\%) were expressed immediately after a student's repair. Surprisingly, however, $47 \%$ of the teachers' signs of approval occurred immediately after errors; this included $32 \%$ before topic continuation and $15 \%$ before recasts. The remaining $19 \%$ occurred immediately after corrective feedback, including 56 after recasts and only 5 after other types of corrective feedback ( 3 following explicit corrections and 2 following clarification requests). Recasts were thus distinguishable from other corrective feedback types in that they often included signs of approval (in 103 instances) as teachers responded affirmatively to the substantive content of students' ill-formed utterances.

To determine whether teachers at least expressed approval more often in response to well-formed utterances than to ill-formed utterances, the cooccurrence of signs of approval was examined with recasts, with noncorrective repetition, and with teacher topic continuation after errors when teachers provided no corrective feedback. As revealed in Table 9, signs of approval occurred in equal proportions across the three types of teacher responses: Approval accompanied $27 \%$ of all 
Table 8. Frequency distribution of signs of approval $(N=319)$ in error sequences

\begin{tabular}{lr}
\hline After repair & $110(34 \%)$ \\
After error & \\
Before topic continuation & $101(32 \%)$ \\
Before recasts & $47(15 \%)$ \\
After feedback & \\
After recasts & $56(17.5 \%)$ \\
After other feedback & $5(1.5 \%)$ \\
\hline
\end{tabular}

Table 9. Co-occurrence of signs of approval with recasts, with noncorrective repetition, and with topic continuation after error

\begin{tabular}{ll}
\hline With recasts & $103 / 377(27 \%)$ \\
With noncorrective repetition & $160 / 617(26 \%)$ \\
With teacher topic continuation after error & $101 / 352(29 \%)$ \\
\hline
\end{tabular}

recasts, $26 \%$ of all noncorrective repetitions, and $29 \%$ of all teacher topiccontinuation moves immediately following errors. Thus, as has been well documented in studies of parent-child interaction (e.g., Brown \& Hanlon, 1970; Hirsh-Pasek et al., 1984; Penner, 1987), truth value rather than well-formedness governs approval of learner responses in these classrooms. Such indiscriminate use of signs of approval, however, indicates that the teachers' purpose in using recasts may indeed not be primarily a corrective one: With regard to approval, recasts have more in common with noncorrective repetition and topic-continuation moves than with other forms of corrective feedback. This reveals what must be a source of ambiguity for young L2 learners as well as a dilemma for teachers whose mandate is to teach both language and content: namely, how to reinforce the substantive content of student messages while giving them clear messages about language form.

\section{DISCUSSION}

Ellis (1995, pp. 139-141) discussed several studies that support a role for negative evidence in SLA (Carroll \& Swain, 1993; Chaudron, 1977; Lightbown, 1991; Lightbown \& Spada, 1990; Pica, 1988; Pica et al., 1989; Tomasello \& Herron, 1988, 1989; White, 1991) and particularly for negative evidence that "incorporates recasts." As this section will demonstrate, however, none of the studies cited support the implicit use of recasts on their own in the way that the four teachers tended to use recasts in the present study. Moreover, some of the studies cited by Ellis in support of recasts suggest that negative evidence is most effective when some type of explicit attention is drawn to the recast (Carroll \& Swain, 1993; Chaudron, 1977; Tomasello \& Herron, $1988,1989)$ or when recasts are abandoned altogether in favor of signals of noncomprehension (Pica, 1988; Pica et al., 1989). Furthermore, other studies cited by Ellis did not directly investigate recasts but provided indirect evidence in favor of correc- 
tive feedback that is relatively explicit (Lightbown, 1991; Lightbown \& Spada, 1990; White, 1991).

Chaudron (1977) found that teacher corrections that elicited student repair were those that "clearly indicated to the student the locus of the error" (as noted by Ellis, 1995, p. 139); this is what Chaudron called repetition with reduction and repetition with emphasis. Indeed, Chaudron found that a more typical recast-what he called repetition with change (but without emphasis or reduction)-was not effective. He found it to be

especially weak in helping to locate the error.... Besides failing clearly to isolate the nature of the error, in many cases the teacher assumes that his correct model is automatically perceived, and he neglects to insure its "intake" by the learner with new elicitative techniques. (pp. 41-42)

Pica (1988) and Pica et al. (1989) found little support for recasts because the latter "required only the NNS's acknowledgement and no need to adjust their linguistic output" (Pica et al., 1989, p. 66). What pushed learners to modify their output, as Ellis noted, were signals of noncomprehension, not recasts.

The Tomasello and Herron $(1988,1989)$ studies did not provide evidence in favor of the implicit provision of recasts either. As Long (1996) has argued, the recasts in these studies were "delivered in the form of explicit correction (the correct forms being written on the blackboard above the students' incorrect ones and commented upon by the teacher, not incidentally)" and were "accompanied by opportunities for unhurried visual inspection and cognitive comparison" (p. 441). Similarly, in the Carroll and Swain (1993) laboratory study of negative evidence, an explicit focus was added to the recast condition: Subjects (in all groups) were told that they would receive feedback only if they made an error, thus eliminating any ambiguity as to the purpose of the recasts. In any case, the group receiving explicit metalinguistic feedback outperformed all groups, including the recast group.

Lightbown and Spada's (1990) classroom study investigated the relationship between explicit instruction and corrective feedback but did not isolate and separately examine recasts. Their findings related to corrective feedback did not provide evidence to support the implicit provision of correct forms. The teacher of the successful ESL learners in their study responded to specific errors mainly with explicit hand signals, a funny face, dramatically raised eyebrows, or "sometimes with a chanted, laughing repetition of the correct form" (p. 440). Lightbown (1991) described in more detail the paralinguistic clues used by this teacher and concluded that "the situations in which the teacher drew students' attention to their be/have error were precisely those situations in which the students knew what they wanted to say and the teacher's intervention made clear to them that there was a particular way to say it" (p. 209, italics added). Similarly, White's (1991) classroom study provided evidence to support explicit instruction that includes negative evidence, but the study did not investigate the effect of recasts: In addition to the explicit instruction, the experimental teachers "were encouraged to point out and correct errors" (p. 141, italics added).

Although these studies generally support a role for negative evidence in SLA, 
including classroom SLA, they do not provide support for or against the implicit provision of recasts in communicatively oriented classrooms. They do suggest, however, that recasts may be beneficial when the learners' attention is intentionally drawn to the corrective reformulation. This concurs with Spada's (1997) conclusion, based on a synthesis of over 30 classroom and laboratory studies investigating the effects of form-focused instruction, that more explicit ways of drawing learners' attention to form are more effective.

A recent classroom study that has directly investigated recasts has indeed demonstrated their benefits when combined with other more explicit signals. Doughty and Varela (in press) conducted a study in two content-based ESL science classrooms with 34 middle-school students (21 in an experimental class and 13 in a control class) ranging in age from 11 to 14 . The targeted features were the simple past and the conditional past because these forms were necessary to accurately report the results of laboratory experiments conducted in these classes. The experimental teacher provided corrective feedback consistently on only these errors. Her corrective intervention each time consisted of two parts: First, some form of attentional focus was provided; second, the recast was provided. For example, in many instances the teacher first repeated the student's erroneous utterance, drawing attention to the errors with stress and rising intonation; if a recast was still necessary, the teacher then provided one, accentuating the correct forms with added stress as in the following example:

José: I think that the worm will go under the soil.

Teacher: I think that the worm will go under the soil?

José: (no response)

Teacher: I thought that the worm would go under the soil.

José: I I thought that the worm would go under the soil.

This type of correction did not occur naturally in the present study's database and indeed proved to be particularly salient for students in the Doughty and Varela study. The investigators reported that, by the second laboratory, students were beginning to self-correct before the teacher had the opportunity to recast and, furthermore, a few students adopted this behavior to correct each other.

Other interventions in the experimental treatment were equally explicit. For example, students also received feedback on their written reports: Errors were circled and reformulated, and students were then asked to rewrite the report. In addition, student presentations were videotaped, then subsequently viewed and paused when errors occurred, at which point the teacher asked the class to repeat the correct forms simultaneously. The overall results indicated a clear advantage for students receiving this type of form-focused intervention.

The Doughty and Varela (in press) study clearly supports a role for corrective feedback as negative evidence in classroom SLA but does not provide evidence that recasts on their own-without additional attention drawn to the corrective reformulation-contribute to classroom SLA. The study's experimental treatment is particularly well designed given the potential ambiguity of recasts employed in teacher-student interaction during content-based lessons, as documented in the pres- 
ent study. The success of the Doughty and Varela study provides direction to both researchers and educators interested in further exploring the effects of various combinations of corrective feedback on classroom SLA.

\section{CONCLUSION}

In Mackey and Philp's (in press) laboratory study, subjects receiving extensive recasts improved even though they modified only $5-6 \%$ of their original utterances in response to the recasts. This led the investigators to suggest that learners' immediate responses to recasts may in fact be red herrings. Indeed, as stated at the beginning of this paper, it is unwarranted to equate learner uptake with L2 learning. However, the analysis of recasts as used by the four immersion teachers in the present study leads to the suggestion that, in studies investigating the effects of negative evidence on classroom SLA, recasts themselves may be red herrings. That is, research on the effects of recasts on classroom SLA has considered not so much the effects of recasts but rather the effects of recasts in combination with more explicit clues; the real issue may thus have more to do with the nature of effective combinations. Several classroom studies concerned with negative evidence in SLA have either operationalized corrective feedback a priori as having a more explicit focus than recasts alone can provide (e.g., Doughty \& Varela, in press; Tomasello \& Herron, 1988, 1989; White, 1991) or found in post hoc analyses of classroom interaction that effective teacher feedback, which allowed learners' attention to be drawn to their errors, was accompanied by explicit paralinguistic signals (Lightbown, 1991; Lightbown \& Spada, 1990) or entailed a reduction of the learner's utterance with added stress for emphasis (Chaudron, 1977). Further experimental studies, which continue to explore the effects of recasts in combination with various types of attentional devices, have much to contribute to research on form-focus in communicative classrooms. Teachers' repetition of learner error, for example, in combination with other feedback types, proved to be effective at leading to repair in the present study. Although repetition of error occurred only once in combination with a recast in the present study's database, this particular combination proved to be successful at improving learners' interlanguage in the Doughty and Varela study.

The findings of the observational study described herein suggest that the four teachers intentionally drew attention to only about one quarter of their recasts by shortening the learner's utterance to locate the error. The remaining three quarters of the teachers' recasts were used in the same ways as noncorrective repetition: ways that kept learners' attention focused on content by primarily providing confirmation or additional information related to the student's message and, to a lesser degree, by seeking confirmation or additional information related to the student's message. These identical discourse functions were distributed equally across recasts and noncorrective repetitions and thus appeared to override any corrective function that may otherwise motivate the reformulations entailed in recasts. The corrective potential of recasts may be further reduced by the various signs of approval that teachers use to react to content, irrespective of well-formedness, and that accompany, again in comparable proportions, recasts, noncorrective repetition, and even topic-continuation moves immediately following errors. This suggests that teachers 
themselves do not consistently use recasts for corrective purposes; it remains unlikely in these instances, therefore, that students perceive any corrective purpose in such recasts.

These findings reveal the equivocal nature of content-based L2 instruction and a concomitant dilemma from a teacher's perspective: namely, how to focus on propositional content and, at the same time, provide clear messages about language form. Similarly, from the perspective of young L2 learners, the findings reveal considerable ambiguity inherent in communicative classroom discourse-ambiguity that has the potential to restrict the development of target-language accuracy in at least two ways: Because ill-formed and well-formed utterances are equally likely to be followed by a variety of confirming and approving moves initiated by teachers, it remains difficult, if not impossible, for young learners, with some degree of reliability, to (a) test hypotheses about the target language and (b) detect input-output mismatches with respect to form.

The consequences of such ambiguity may be further considered in terms of Vigil and Oller's (1976) model of extrinsic feedback and their argument that factors governing fossilization in SLA are primarily pragmatic ones ranging from positive to negative feedback on a cognitive channel and an affective channel. In this view, whether the teacher's semantically contingent response is a recast following a student's ill-formed utterance or a noncorrective repetition following a student's wellformed utterance, both provide positive feedback on the cognitive channel in that they both confirm that the student's message has been understood (with the possible exception of the $8-12 \%$ that were interrogative forms serving as confirmation checks, but this is equally true for recasts and noncorrective repetitions). Furthermore, recasts and noncorrective repetition (and even topic-continuation moves following errors) are equally likely to provide positive affective feedback (particularly, but not only, those including various signs of approval) insofar as they convey to students the message that "more of the same" (p. 286) is desirable. Vigil and Oller argued that this particular feedback condition, combining positive cognitive and affective feedback, is apt to produce fossilization of errors (but see Selinker \& Lamendella, 1978, 1979, for other perspectives on fossilization). ${ }^{9}$ Vigil and Oller argued that a more favorable feedback condition would combine positive affective feedback and negative cognitive feedback, the latter indicating some problem in comprehension or that changes in the learner's output are desirable.

Notwithstanding the questionable effectiveness of recasts as corrective feedback, recasting clearly provides teachers with efficient ways of advancing the lesson by keeping students' attention focused on content in spite of gaps in L2 proficiency. This may explain why recasts have proven to be so frequent in immersion contexts. Furthermore, recasts serve as positive evidence in classroom settings, in the same way that noncorrective repetitions do, in that they both provide learners with exemplars of what is possible in the L2. As positive evidence, however, recasts do not convey to learners what is unacceptable in the language. As Marcus (1993, p. 59) has argued with respect to $\mathrm{L} 1$ development, recasts do not indicate whether the corrective reformulation is simply a stylistic variant or synonym, or whether the learner's utterance is unacceptable. Morgan et al. (1995) argued that, for recasts to be noticed as negative evidence in $\mathrm{L} 1$ development, children must be able to discriminate 
recasts from other types of parental replies, interpret recasts as manifesting corrective feedback, and reevaluate their current grammars in light of the corrective feedback. However, they argued that (a) there is nothing distinctive about the forms of recasts relative to other types of repetition (i.e., recasts and noncorrective repetitions are distinguishable only in relation to the learner's previous utterance); (b) there is nothing intrinsically corrective in the forms and meanings of recasts (as supported by the present study's findings); and (c) recasts do not inform children how to formulate appropriate grammatical modifications any more than do other forms of positive evidence. The authors concluded by attributing a noncorrective function to recasts: namely, to encourage diversity of usage, imparting the message, "That was one way of saying it. Now here's another" (p. 195).

Finally, the small amount of learner uptake, as opposed to the large number of topic-continuation moves initiated by teachers after recasts, suggests that recasts allow teachers to keep the floor. In this sense, recasts at times signal a transmission model of instruction wherein teachers do the work, so to speak, while students remain passive, thus reinforcing the unequal distribution of participation rights between teachers and students in classroom interaction as described by Pica (1987). In Oliver's (1995) study of child NS-NNS dyads, NNSs incorporated only about $10 \%$ of the NS recasts. However, turns in which a nonnative-speaker incorporation of a native-speaker recast was either impossible (i.e., NS holds the floor) or inappropriate (i.e., recast is a yes/no question serving as a confirmation check) were finally excluded from the analysis of NNS reactions. This increased the proportion of NNS incorporations of NS recasts from $10 \%$ to $35 \%$, a finding considered to reflect a methodological advance in studies of dyadic interaction (Long, 1996; Mackey \& Philp, in press). In the case of teacher-student interaction, however, teachers indeed use recasts in ways that do not provide learners with frequent opportunities in which it is either appropriate or even possible to incorporate the reformulation. Accordingly, one needs precisely to take account of such instances in order to examine the overall propensity of recasts to draw learners' attention to form. In particular, the teachers' frequent topic-continuation moves following recasts are more likely to draw attention to content than to form, reducing even further the chances of young learners to detect any input-output mismatches.

In conclusion, recasts do not allow for much negotiation to occur between teachers and young classroom learners in ways that intentionally draw students' attention to form and that productively engage students as participants in the discourse. Instead, when the four teachers in this study did attempt to draw their students' attention to form during meaning-related interaction in ways that invited students to participate in the negotiation, they tended to exploit the interactional moves previously characterized as the negotiation of form (Lyster, 1994; Lyster \& Ranta, 1997), including, in particular, the use of elicitation techniques and metalinguistic clues. Further investigation of such interactional moves lies ahead in experimental studies designed to manipulate a variety of corrective feedback variables in classroom settings.

(Received 17 February 1997) 


\section{NOTES}

1. The word girafe is feminine and thus requires the feminine article la, not le.

2. Pretests and posttests, in addition to the six models and six recasts provided, were completed in $\mathbf{4 0}$ minutes for the Japanese study and 60 minutes for the Spanish study.

3. Teachers 1 and 2 both teach at the Grade 6 level. The interactional data from their classrooms have not yet been analyzed. The labels $\mathrm{T} 3, \mathrm{~T} 4, \mathrm{~T} 5$, and T6 are used in this paper to maintain consistency throughout subsequent reports deriving from this study.

4. In the examples that have been extracted from the database, the following conventions apply. Each example is identified according to teacher (T3, T4, T5, T6), lesson, and date (see appendix for details). St refers to student, and slashes (//) enclose words said in English. Square brackets enclose comments or coding tags, which have been included where appropriate. For more information on how various errors were coded, see Lyster (in press). Attempts have been made, where possible, to reflect the source of errors in the translations.

5. What needs to be clarified, then, is whether recasting is separate from, or part of, what has been referred to as "negotiation for meaning" (cf. Long, 1996).

6 . For coding schemes that appear to preclude the coding of recasts that incorporate new information, see Demetras et al. (1986), Doughty (1994), and Hirsh-Pasek et al. (1984).

7. Similar findings have been reported in L1 contexts by Bohannon and Stanowicz (1988) and Farrar (1992). The latter (Farrar, 1992, p. 95) concluded that, because Ll children imitate corrective recasts more frequently than other parental responses, they must be responding to the negative feedback and not simply to the imitation. However, the children in his study were also significantly more likely to repeat their original ungrammatical sentence following corrective recasts than following other parental responses (see Morgan et al., 1995).

8. The rates of repair and uptake (uptake $=$ repair + needs-repair) for the six feedback types presented in Lyster and Ranta (1997) were as follows:

$\begin{array}{lcc} & \text { Repair } & \text { Uptake (repair + needs-repair) } \\ \text { Elicitation } & 46 \% & 100 \% \\ \text { Metalinguistic clues } & 45 \% & 86 \% \\ \text { Clarification request } & 28 \% & 88 \% \\ \text { Repetition of error (in isolation) } & 31 \% & 78 \% \\ \text { Explicit correction } & 37 \% & 50 \% \\ \text { Recast } & 18 \% & 31 \%\end{array}$

9. Similarly, referring specifically to the ambiguity of error treatment as observed in immersion classrooms (see Swain \& Carroll, 1987), Lapkin, Swain, and Shapson (1990) concluded that it is "perhaps not surprising that errors persist in the French used by immersion students" (p. 655).

\section{REFERENCES}

Allen, P., Swain, M., Harley, B., \& Cummins, J. (1990). Aspects of classroom treatment: Toward a more comprehensive view of second language education. In B. Harley, P. Allen, J. Cummins, \& M. Swain (Eds.), The development of bilingual proficiency (pp. 57-81). New York: Cambridge University Press.

Allwright, D. (1975). Problems in the study of the language teacher's treatment of learner error. In M. Burt \& $\mathrm{H}$. Dulay (Eds.), New directions in second language learning, teaching and bilingual education: On TESOL '75 (pp. 96-109). Washington, DC: TESOL.

Allwright, D., \& Bailey, K. (1991). Focus on the language classroom. New York: Cambridge University Press.

Bohannon, J. N., III, \& Stanowicz, L. (1988). The issue of negative evidence: Adult responses to children's language errors. Developmental Psychology, 24, 684-689.

Brock, C., Crookes, G., Day, R., \& Long, M. (1986). The differential effects of corrective feedback in native speaker-nonnative speaker conversation. In R. Day (Ed.), Talking to learn (pp. 229-236). Rowley, MA: Newbury House.

Brown, R., \& Hanlon, C. (1970). Derivational complexity and order of acquisition in child speech. In J. R. Hayes (Ed.), Cognition and the development of language (pp. 11-53). New York: Wiley.

Calvé, P. (1992). Corriger ou ne pas corriger, la n'est pas la question. The Canadian Modern Language Review, $48,458-471$.

Carroll, S., \& Swain, M. (1993). Explicit and implicit negative feedback: An empirical study of the learning of linguistic generalizations. Studies in Second Language Acquisition, 15, 357-386. 
Chaudron, C. (1977). A descriptive model of discourse in the corrective treatment of learners' errors. Language Learning, 27, 29-46.

Chaudron, C. (1988). Second language classrooms. New York: Cambridge University Press.

Corder, S. P. (1967). The significance of learners' errors. International Review of Applied Linguistics, 4, 161170.

Demetras, M., Post, K., \& Snow, C. (1986). Feedback to first language learners: The role of repetitions and clarification requests. Journal of Child Language, 13, 275-292.

Doughty, C. (1994). Finetuning of feedback by competent speakers to language learners. In J. Alatis (Ed.) Georgetown University Round Table (GURT) 1993 (pp. 96-108). Washington, DC: Georgetown University Press.

Doughty, C., \& Varela, E. (in press). Communicative focus on form. In C. Doughty \& J. Williams (Eds.), Focus on form in classroom SLA. New York: Cambridge University Press.

Ellis, N. (1995). Consciousness in second language acquisition: A review of field studies and laboratory experiments. Language Awareness, 4, 123-146.

Ellis, R. (1997). Second language acquisition. New York: Oxford University Press.

Fanselow, J. (1977). The treatment of error in oral work. Foreign Language Annals, 10, 583-593.

Farrar, M. J. (1990). Discourse and the acquisition of grammatical morphemes. Journal of Child Language, $17,607-624$.

Farrar, M. J. (1992). Negative evidence and grammatical morpheme acquisition. Developmental Psychology, 28, 90-98.

Fazio, L., \& Lyster, R. (1997). COLT comparisons of second language learning environments in minority language and immersion classrooms. Manuscript submitted for publication.

Gass, S. (1988). Integrating research areas: A framework for second language studies. Applied Linguistics, 9, 198-217.

Gass, S., \& Varonis, E. (1989). Incorporated repairs in nonnative discourse. In M. Eisenstein, (Ed.), The dynamic interlanguage: Empirical studies in second language variation (pp. 71-86). New York: Plenum Press.

Gass, S., \& Varonis, E. (1994). Input, interaction, and second language production. Studies in Second Language Acquisition, 16, 283-302.

Harley, B. (1993). Instructional stategies and SLA in early French immersion. Studies in Second Language Acquisition, 15, 245-260.

Harley, B. (1994). Appealing to consciousness in the L2 classroom. AlLA Review, 11, 57-68.

Hendrickson, J. (1978). Error correction in foreign language teaching: Recent theory, research, and practice. Modern Language Journal, 62, 387-398.

Hirsh-Pasek, K., Treiman, R., \& Schneiderman, M. (1984). Brown \& Hanlon revisited: Mothers' sensitivity to ungrammatical forms. Journal of Child Language, 11, 81-88.

Hulstijn, J. (1990). A comparison between the information-processing and the analysis/control approaches to language learning. Applied Linguistics, 11, 30-45.

Lapkin, S., Swain, M., \& Shapson, S. (1990). French immersion research agenda for the 90s. The Canadian Modern Language Review, 46, 638-674.

Lightbown, P. M. (1991). What have we here? Some observations on the role of instruction in second language acquisition. In R. Phillipson, E. Kellerman, L. Selinker, M. Sharwood Smith, \& M. Swain (Eds.), Foreign/ second language pedagogy research: A commemorative volume for Claus Fœrch (pp. 197-212). Clevedon, UK: Multilingual Matters.

Lightbown, P. M., \& Spada, N. (1990). Focus-on-form and corrective feedback in communicative language teaching: Effects on second language learning. Studies in Second Language Acquisition, 12, 429-448.

Long, M. (1977). Teacher feedback on learner error: Mapping cognitions. In H. D. Brown, C. A. Yorio, \& R. H. Crymes (Eds.), On TESOL '77 (pp. 278-293). Washington, DC: TESOL.

Long, M. (1996). The role of the linguistic environment in second language acquisition. In W. C. Ritchie \& T. K. Bhatia (Eds.), Handbook of language acquisition: Vol. 2. Second language acquisition (pp. 413468). New York: Academic Press.

Long, M., Inagaki, S., \& Ortega, L. (in press). The role of implicit negative evidence in SLA: Models and recasts in Japanese and Spanish. The Modern Language Journal.

Lyster, R. (1994). La négociation de la forme : Stratégie analytique en classe d'immersion. The Canadian Modern Language Review, 50, 447-465.

Lyster, R. (1995, March). Negotiation of form in communicatively oriented classrooms. Paper presented at the American Association of Applied Linguistics (AAAL) Conference, Long Beach, CA.

Lyster, R. (in press). Negotiation of form, recasts, explicit correction in relation to error types and learning repair in L2 classrooms. Language Learning, 48.

Lyster, R., \& Ranta, L. (1995, October). Getting learners to notice: Negotiation of form as negative evidence. Paper presented at Second Language Research Forum '95, Cornell University, NY. 
Lyster, R., \& Ranta, L. (1997). Corrective feedback and learner uptake: Negotiation of form in communicative classrooms. Studies in Second Language Acquisition, 19, 37-66.

Mackey, A., \& Philp, J. (in press). Conversational interaction and second language development: Recasts, responses, and red herrings. The Modern Language Journal.

Marcus, G. (1993). Negative evidence in language acquisition. Cognition, 46, 53-85.

McLaughlin, B. (1990). Restructuring. Applied Linguistics, 11, 113-128.

Morgan, J., \& Travis, L. (1989). Limits on negative information in languge input. Journal of Child Language, $16,531-552$.

Morgan, J., Bonamo, K., \& Travis, L. (1995). Negative evidence on negative evidence. Developmental Psychology, 31, 180-197.

Netten, J. (1991). Towards a more language oriented second language classroom. In L. Malav \& G. Duquette (Eds.), Language, culture and cognition (pp. 284-304). Clevedon, UK: Multilingual Matters.

Nobuyoshi, J., \& Ellis, R. (1993). Focused communication tasks and second language acquisition. ELT Journal, $47,203-210$.

Oliver, R. (1995). Negative feedback in child NS-NNS conversation. Studies in Second Language Acquisition, $17,459-481$.

Penner, S. (1987). Parental responses to grammatical and ungrammatical child utterances. Child Development, 58, 376-384.

Pica, T. (1987). Second-language acquisition, social interaction, and the classroom. Applied Linguistics, 8, 3-21.

Pica, T. (1988). Interlanguage adjustments as an outcome of NS-NNS negotiated interaction. Language Learning, 38, 45-73.

Pica, T., Holliday, L., Lewis, N., \& Morgenthaler, L. (1989). Comprehensible output as an outcome of linguistic demands on the learner. Studies in Second Language Acquisition, 11, 63-90.

Richards, B. (1994). Child-directed speech and influences on language acquisition: Methodology and interpretation. In C. Galloway \& B. Richards (Eds.), Input and interaction in language acquisition (pp. 74-106). New York: Cambridge University Press.

Roberts, M. (1995). Awareness and the efficacy of error correction. In R. Schmidt (Ed.), Attention and awareness in foreign language learning (Tech. Rep. No. 9, pp. 162-182). Honolulu: University of Hawaii, Second Language Teaching and Curriculum Center.

Saxton, M. (1997). The Contrast Theory of negative input. Journal of Child Language, 24, 139-161.

Schachter, J. (1983). Nutritional needs of language learners. In M. Clarke \& J. Handscombe (Eds.), On TESOL '82: Pacific perspectives on learning and teaching (pp. 175-189). Washington, DC: TESOL.

Schmidt, R. (1990). The role of consciousness in second language learning. Applied Linguistics, 11, 129-158.

Schmidt, R. (1993). Awareness and second language acquisition. Annual Review of Applied Linguistics, 13, 206-226.

Schmidt, R., \& Frota, S. (1986). Developing basic conversational ability in a second language: A case study of an adult learner of Portuguese. In R. Day (Ed.), Talking to learn (pp. 237-326). Rowley, MA: Newbury House.

Selinker, L., \& Lamendella, J. (1978). Two perspectives on fossilization in interlanguage learning. Interlanguage Studies Bulletin, 3, 143-191.

Selinker, L., \& Lamendella, J. (1979). The role of extrinsic feedback in interlanguage fossilization: A discussion of "Rule fossilization: A tentative model." Language Learning, 29, 363-375.

Snow, C. (1988). Conversations with children. In P. Fletcher \& M. Garman (Eds.), Language acquisition (2nd. ed.) (pp. 69-89). New York: Cambridge University Press.

Spada, N. (1997). Form-focussed instruction and second language acquisition: A review of classroom and laboratory research. Language Teaching, 29, 1-15.

Spada, N., \& Fröhlich, M. (1995). COLT. Communicative Orientation of Language Teaching observation scheme: Coding conventions and applications. Sydney, Australia: National Centre for English Language Teaching and Research.

Swain, M. (1985). Communicative competence: Some roles of comprehensible input and comprehensible output in its development. In S. Gass \& C. Madden (Eds.), Input in second language acquisition (pp. 235253). Rowley, MA: Newbury House.

Swain, M. (1988). Manipulating and complementing content teaching to maximize second language learning. TESL Canada Journal, 6, 68-83.

Swain, M. (1993). The output hypothesis: Just speaking and writing aren't enough. The Canadian Modern Language Review, 50, 158-164.

Swain, M. (1995). Three functions of output in second language learning. In G. Cook \& B. Seidlhofer (Eds.), Principles and practice in applied linguistics: Studies in honour of H. G. Widdowson (pp. 125-144). New York: Oxford University Press.

Swain, M. (1996). Integrating language and content in immersion classrooms: Research perspectives. The Canadian Modern Language Review, 52, 529-548. 
Swain, M., \& Carroll, S. (1987). The immersion observation study. In B. Harley, P. Allen, J. Cummins, \& M. Swain (Eds.), Development of bilingual proficiency. Final report. Vol. II: Classroom treatment. Toronto, Canada: Modern Language Centre, Ontario Institute for Studies in Education.

Thornton, I., \& Pienemann, M. (1994). COALA: Computer-aided linguistic analysis. Sydney, Australia: Language Acquisition Research Centre.

Tomasello, M., \& Herron, C. (1988). Down the Garden Path: Inducing and correcting overgeneralization errors in the foreign language classroom. Applied Pycholinguistics, 9, 237-246.

Tomasello, M., \& Herron, C. (1989). Feedback for language transfer errors: The Garden Path technique. Studies in Second Language Acquisition, 11, 385-395.

Towell, R., Hawkins, R., \& Bazergui, N. (1996). The development of fluency in advanced learners of French. Applied Linguistics, 17, 84-119.

van Lier, L. (1988). The classroom and the language learner. London: Longman.

Vigil, N., \& Oller, J. (1976). Rule fossilization: A tentative model. Language Learning, 26, 281-295.

White, L. (1991). Adverb placement in second language acquisition: Some effects of positive and negative evidence in the classroom. Second Language Research, 7, 133-161. 


\section{APPENDIX}

\section{DATABASE}

4 teachers

13 French Language Arts lessons ( $467 \mathrm{~min}=7.8 \mathrm{hrs}$.)

14 subject matter lessons: science, social studies, math $(633 \mathrm{~min}=10.5 \mathrm{hrs}$.)

27 lessons totaling 1,100 minutes or 18.3 hours

School Board A-Early total immersion

Teacher 3 (Grade 4)-11 lessons (340 $\mathrm{min}$ )

1. Jan. 16 Language arts-prereading activity about meteorology $20 \mathrm{~min}$

2. Jan. 16 Language arts-reading (La météorologie en folie) $30 \mathrm{~min}$

3. Jan. 16 Science-mammals' means of adapting to environment $65 \mathrm{~min}$

4. Jan. 16 Math-geometric translations $40 \mathrm{~min}$

5. Jan. 30 Social studies-the first settlers $15 \mathrm{~min}$

6. Feb. 6 Language arts-reading (Les best-sellers) $45 \mathrm{~min}$

7. Mar. 6 Language arts-writing letters to companies $15 \mathrm{~min}$

8. Mar. 8 Language arts-discussion (paying youth for chores) $20 \mathrm{~min}$

9. Mar. 20 Language arts-discussion about vacation $25 \mathrm{~min}$

10. Mar. 20 Language arts-reading (Camomille la sorcière) $20 \mathrm{~min}$

11. Mar. 29 Language arts-students' poetry $45 \mathrm{~min}$

School Board B-Middle immersion

Teacher 4 (Grades 4/5)-4 lessons (250 min)

1. Mar. 17 Science-students present science experiments $50 \mathrm{~min}$

2. Mar. 17 Language arts-role plays to reenact story $85 \mathrm{~min}$

3. Mar. 24 Math-measurement and estimation $40 \mathrm{~min}$

4. Mar. 31 Social studies-discovery of North America $75 \mathrm{~min}$

Teacher 5 (Grade 4)-8 lessons (325 min)

1. Mar. 14 Language arts-classified ads $50 \mathrm{~min}$

2. Mar. 21 Language arts-discussion about long weekend $12 \mathrm{~min}$

3. Mar. 21 Science-zoo animals $45 \mathrm{~min}$

4. Mar. 28 Science-animals (habitat, sounds, movement) $58 \mathrm{~min}$

5. Apr. 4 Science-bread and cereal food group $50 \mathrm{~min}$

6. Apr. 11 Science-animals (oral presentations) $35 \mathrm{~min}$

7. Apr. 11 Social studies-manufacturing of Whippet cookies $15 \mathrm{~min}$

8. Apr. 25 Science-water cycle $60 \mathrm{~min}$

Teacher 6 (Grade 4)-4 lessons (185 min)

1. Apr. 3 Language arts-reading (La cabane à sucre) $55 \mathrm{~min}$

2. Apr. 10 Language arts-reading (Easter) $45 \mathrm{~min}$

3. Apr. 27 Science-animals $50 \mathrm{~min}$

4. May 11 Science-the field mouse and review of body parts $35 \mathrm{~min}$ 